\title{
Impacts of Agricultural Land Acquisition for Urbanization on Agricultural Activities of Affected Households: A Case Study in Huong Thuy Town, Thua Thien Hue Province, Vietnam
}

\author{
Nhung Pham Thi ${ }^{1,2, *(\mathbb{D}, \text { Martin Kappas }}{ }^{1}\left(\mathbb{D}\right.$ and Heiko Faust ${ }^{3}(\mathbb{D}$ \\ 1 Division of Cartography, GIS and Remote Sensing, Faculty of Geoscience and Geography, \\ Georg-August University Goettingen, 37077 Goettingen, Germany; mkappas@gwdg.de \\ 2 Hue University of Agricultural and Forestry, Hue University, Hue 530000, Vietnam \\ 3 Division of Human Geography, Faculty of Geoscience and Geography, Georg-August University Goettingen, \\ 37077 Goettingen, Germany; hfaust@gwdg.de \\ * Correspondence: nhungphamthihuaf@gmail.com or nhung.pham-ti@geo.uni-goettingen.de; \\ Tel.: +84-944-495-372
}

\section{check for} updates

Citation: Pham Thi, N.; Kappas, M.; Faust, H. Impacts of Agricultural Land Acquisition for Urbanization on Agricultural Activities of Affected Households: A Case Study in Huong Thuy Town, Thua Thien Hue Province, Vietnam. Sustainability 2021, 13, 8559. https://doi.org/10.3390/ su13158559

Academic Editor: Susana

Martín-Fernández

Received: 14 June 2021

Accepted: 28 July 2021

Published: 31 July 2021

Publisher's Note: MDPI stays neutral with regard to jurisdictional claims in published maps and institutional affiliations.

Copyright: (c) 2021 by the authors. Licensee MDPI, Basel, Switzerland. This article is an open access article distributed under the terms and conditions of the Creative Commons Attribution (CC BY) license (https:// creativecommons.org/licenses/by/ $4.0 /)$.

\begin{abstract}
Agricultural land acquisition for urbanization (ALAFU) has strongly impacted agriculture in Vietnam during the last decades. Given the mixed data obtained from a survey (with 50 households who lost $50 \%$ of their farmland area), in-depth interviews, a group-focused discussion and observation, this study shows the different impacts of ALAFU on each agricultural activity of affected household by comparing before and after ALAFU. Rice cultivation and animal breeding have sharply declined, but potted flower plantation (PFP) has quickly grown and is the main income of $34 \%$ of surveyed households. Rice cultivation has declined not only as a result of agricultural land acquisition, which has resulted in the loss of rice land, but also as a result of urbanization, which has resulted in rice land abandonment. Conversely, PFP is growing due to advantages associated with urbanization, such as a good consumer market and upgraded infrastructure. However, whether they are declining or increasing, all agricultural activities have to face challenges related to the shortcomings in agricultural land allocation and agricultural development plans. This study suggests that if ALAFU projects are continued, the government should evaluate agricultural development and forecast farmland abandonment after ALAFU. Simultaneously, they should put more effort into maintaining agriculture in the form of peri-urban or urban agriculture, which is significant for sustainable development in affected communities.
\end{abstract}

Keywords: agricultural land acquisition; urbanization; farmland fragmentation; farmland abandonment; peri urban agriculture; potted flower plantation

\section{Introduction}

After more than two decades of implementing the national strategy of industrialization and urbanization, many parts of rural area in Vietnam have quickly transformed to periurban or urban areas, and rural people's livelihoods have gradually moved to the nonfarming sector [1]. The statistical data of the country in 2019 shows that the contribution from the non-agriculture sector to the national GDP and its share of employment increased to $82 \%$ and $64.7 \%$, respectively. Previous studies have revealed that taking non-farm jobs is a good alternative livelihood strategy that affected people should pursue following agricultural land acquisition (ALA), to restore and improve their economic household [2,3]. This is one of the important achievements of urbanization and industrialization [4].

However, estimations about 10 million hectares of land (agricultural land and forestland) in Vietnam were acquired and converted to support the above strategy. Meanwhile, agricultural land resources in Vietnam are essentially poor compared with other developing countries in Southeast Asia [5,6]. Moreover, in recent years, many farmers have 
left farm jobs in rural areas to obtain non-farm jobs in cities, resulting in wasted farmland resources [7]. This situation could be more serious in communities affected by ALAFU, where almost all farmers have lost a part of farmland and have more opportunities to take non-farming jobs. As in many developing countries such as China, India and Indonesia, Vietnam's economic development is advancing toward diversifying occupation structure, agriculture is not only one of the crucial economic sectors of the country, but it also plays important roles in food security, food safety, and protecting the landscape and environment in both rural and urban areas [8-10]. Therefore, going along with fostering urbanization, developing sustainable agriculture and protecting farmland resources has also been mentioned in the sustainable economic development strategy of the nation [5]. So, what happens to the remaining farmland areas and agriculture in affected communes after ALAFU? Exploring this issue is necessary not only to make a good farmland use plan, but also to find out potential solutions for agricultural development in the context of farmland limitation, which will be more serious in the future in developing countries. It also supports the creation of livelihood rehabilitation plans for affected households.

Unfortunately, having focused primarily on analyzing non-farm jobs and gaps in land acquisition policy, previous studies did not pay much attention to sustainable agricultural development after ALA. Therefore, we conducted the study with the following research questions: (1) how have the agricultural activities of affected households changed under the impact of ALAFU, (2) how does each agricultural activity contribute to household incomes after ALAFU, (3) what determines these agricultural activities after ALAFU, and (4) are there any challenges and opportunities for each agricultural activity by ALAFU? To answer these questions, Huong Thuy town, located in Thua Thien Hue province, Vietnam, has been selected to be our study site because a large area of agricultural land has been acquired here since the 2000s to support Hue city's expansion. The research findings show the transformation of each agricultural activity and its roles, and discover the challenges and opportunities after ALAFU. Given these findings, we recommend whether agricultural activities should continue or be replaced by non-farm activities in affected communities. We assume that agricultural activities and their contribution to household income after ALAFU have gradually decreased and that difficulties and challenges have increased further under the pressure of urbanization than advantages and opportunities.

\section{Context of Research}

\subsection{Agriculture Transformation in Vietnam}

Vietnamese agriculture, a leading income source in rural households, has been a crucial economic element of the country. Having changed positively by applying the Doi Moi policy in 1986 and the land law in 1993, agriculture has transformed the country from a food-insecure country to one of the world's top exporters of agricultural products such as coffee, rice, and pepper [5]. During the 1990s, the Vietnamese Government promoted expanding agriculture to uncultivated land areas in remote rural communes. Since the 2000s, when almost all the uncultivated land area was exploited, new-tech agriculture has been intensively applied to obtain high yields and output. Throughout this period, overusing fertilizer and pesticides and overexploiting agricultural land has primarily resulted in agriculture with rapid growth. As a result, in only 15 years (1995-2010), Vietnam transitioned from an agriculture-based to a transition country [5]. As a result, agriculture has been dealing with serious pollution of land and water resources, which threatens sustainable agricultural development [11-13]. Although showing many positive changes, Vietnamese agriculture is still in the stages of low value-added products compared with the global value chain [14]. Recently, the models of clean agriculture, bio-agriculture, and climate-smart agriculture have been considered and applied, aiming for sustainable agricultural development. This has been the newly emerged tendency for Vietnamese agriculture $[13,15]$. This situation of agriculture in Vietnam is rather similar to those in other developing countries, especially China [16,17]. 
Besides, labor productivity in the agriculture sector is low, only $30 \%$ in the industry sector and $33.7 \%$ in the service sector [11]. A startling statistic is that nearly half of all households that were solely engaged in agriculture in 2008 had found another income activity at least by 2010 [5]. Agriculture contributed by $19.9 \%$ to national household income in 2012, down from $28.6 \%$ in 2002. Primary agriculture's income share in rural households was $31.8 \%$ in 2012 , down from $43.4 \%$ in 2002 , and had been surpassed in proportion by "salaries and wages" in 2010 [5]. Farming is losing its importance and position in rural household livelihoods in Vietnam in particular, and in Southeast Asian countries in general [1].

Although being less attractive in rural areas, agriculture has emerged in places on the fringes of urban areas, which had been former rural areas before ALAFU, called Peri-Urban or Urban Agriculture (PUA). Although PUA is considered a marginal activity in urban areas, it continues to make a significant contribution to urban households' food security and income [18]. Several studies have indicated that the maintenance and development of PUA is one of the solutions to reduce the negative impacts of urbanization $[19,20]$. As in other developing countries, PUA in Vietnam contributes to and diversifies household income, reduces economic risk, ensures food security, and generates job opportunities for family laborers who cannot find new off-farm jobs in the labor market after ALAFU $[9,21,22]$. In other aspects, PUA plays a significant role in the maintenance of traditional community relationships and the environment [23].

In 2016, due to the effort of agricultural development and management under the context of urbanization, 9.32 million households were participating in the agriculture sector [24] which plays a central role in food security, poverty reduction, and foreign exchange earnings in Vietnam [25]. The structure of agriculture has changed between livestock and cultivation. While cultivation (a traditional long-lasting activity of Vietnamese agriculture with main crops such as rice, coffee, cashews, and pepper) has not changed much, livestock farming (an emerging sector in the last decades with main animals such as poultry, pigs, and cattle) has been notably developing $[11,26]$. The agricultural production scale of Vietnam is smaller than that of other Southeast Asian countries [27] and is rather similar to that of China [28]. Cultivation with a scale over 2 ha is still limited, but a number of livestock farms at larger scales are developing. Comparing between 2006 and 2011, the percentage of households breeding pigs with over 50 units increased by $80 \%$, and the number of households breeding poultry with over 1000 units increased by 4.32 times. In general, however, the total of breeding households decreased by $35 \%$ and the households breeding pigs at a small scale (1-2 units) still counted for $50 \%$ of total pig breeding households in 2011 [29]. In the period 2017-2019, the livestock was faced with the outbreak of African Swine Fever (ASF) and H5N1, leading to a sharp reduction of production [30].

\subsection{Agricultural Land Resource in Vietnam}

In Vietnam, the State is the representative owner of land resources. They manage the land, make land use planning decisions, and distribute the land to land users (individuals and organizations) through the issuance of land use rights certificates. With agricultural land, the State delivered the long-term land use rights equally to all rural people in 1993 (the first version of land law in Vietnam), aiming for efficient agriculture [31]. Agricultural land users have the right to use, sub-rent, inherit, and sell their agricultural land to other users, but they have to pay land tax and to return the land use rights when the State requests, to support national development purposes. When returning the land use rights to the State, land users will be compensated by cash or new land areas that are equal to or larger than their acquired land areas, but only the State has the authority to determine the price of agricultural acquired land [26,31,32]. Moreover, there has not been much change in agricultural land redistribution since 1993, leading to the young generation (born after 1993) in rural areas or in farmers' households not being issued agricultural land use rights. This could be one of the reasons why many young laborers in rural areas have not 
chosen the agricultural sector to work in. Having the same land tenure system as China, the land-use rights of farmers in Vietnam have been significantly advanced over recent decades by referring to experience and learning from the land policy of this country [33].

Going with establishing and improving the land law over time, the Government also made efforts to expand agricultural land, which is poor compared with other Asian countries. Since the 1990s, the Government expanded agricultural land by promoting domestic migration to reclaim the uncultivated land in remote rural areas, leading to an increase of almost $70 \%$ of the total agricultural land area during this period. This continued to increase slightly in the 2000s [26]. By 2012, the total crop land area reached 10.8 million ha, composing $35 \%$ of the total agricultural land resources of the country, in which $60 \%$ cultivates annual crops, $34 \%$ cultivates perennial crops and $6 \%$ is grassland supporting cow livestock [26]. The average arable area per agriculturally active person in the country is 0.34 ha, which is roughly half that of Cambodia, the Philippines or Myanmar [5]. Agricultural households or farms own nearly $90 \%$ of agricultural land, and the average land area per household is small. The percentage of households with less than 0.2 hectares, between 0.2 and 0.5 hectares, between 0.5 and 1 hectares, between 1 and 2 ha, and more than 2 hectares is $30 \%, 26 \%, 18 \%, 15 \%$, and $12 \%$, respectively. Furthermore, agricultural land was distributed in an equitable manner to individuals, which means that each household has several plots in different locations based on differences in soil quality, access to water sources, and distance [14]. This led to cropland fragmentation, where each household often has $4-5$ plots in different places [34]. This situation also occurs in China, where each household has around six plots [28]. Recent studies have shown that a small area of farmland and fragmentation caused limitations on agricultural growth $[11,34]$. Therefore, to improve efficiency of agriculture, Government implemented land consolidation programs in many communes around the country. Hence, between 2004-2014, the plot number per household was reduced slightly from 4.27 to 2.83 [14,35].

While agricultural land fragmentation and scarcity are still mentioned as considerable constraints on agricultural modernization, it could be exacerbated in affected communes due to a huge area of agricultural land acquired to support to urbanization and industrialization [36]. According to GSO, the rice land area has been reduced by about 2.6 million hectares, while nonagricultural land area increased 1.8 million hectares in the period 1995-2009 [37]. About 10 million ha of land (agricultural land and forest land) was converted to other types of land in the last three decades [6]. Moreover, most of the converted land area is flat land located in lowland areas where agricultural activities could have more convenience than upland areas and others [38].

This phenomenon has also been occurring around the world. If current trends in population density continue and all areas with high probabilities of urban expansion undergo change, then by 2030 the urban land cover of the world will increase by 1.2 million $\mathrm{km}^{2}$, nearly tripling the global urban land area circa 2000 . As a result, $1.8-2.4 \%$ of global croplands will be lost. Of that, $80 \%$ will occur in Asia and Africa [39,40]. Notably, much of the cropland that will be lost is more than twice as productive as national averages. Asia will experience the highest absolute loss of cropland, whereas African countries will experience the highest percentage loss of cropland [39]. The problem of farmland conversion is witnessed all over the world [12]. In developing Asian countries, losing farmland associated with urbanization has been especially rapid and has been recognized as a silent disaster [41]. In 1996-2003, around 6.7 million hectares of farmland in China were lost to economic development of the country [42,43]. In Indonesia, the conversion of land use from irrigated paddy fields to non-agricultural purposes reached 110,000 hectares, per [44].

\subsection{Urbanization in Vietnam}

Until 2018, a total of 833 urban areas had been formed in Vietnam with an urbanization percentage of around $38.5 \%$. This figure is expected to increase by $50 \%$ by 2025 [45,46]. Between 1990 and 2017, the urban population has increased from 19.51 to 35.03 million 
people $[47,48]$. In general, despite great achievement of the national economy, Vietnam is facing numerous challenges caused by rapid urbanization, which is placing burdens on its technical and social infrastructure and leading to many severe consequences [45]. The national economic situation has been sharply improved, but conversion of massive areas of agricultural land to urban land as mentioned above has strongly impacted on agricultural land loss [49]. According to the Vietnam Farmers' Union, between 2003 and 2008, land conversion has affected the livelihoods of 2.5 million people, with over $53 \%$ of these households experiencing a reduction in income after land conversion [50]. Moreover, urbanization also promotes the movement of almost all young labor and male labor from rural to non-farm jobs in cities, leading to aging and feminization of labor in the agricultural sector [51]. In addition, due to inefficient management of ALAFU projects, the urbanization process has changed a part of acquired agricultural land into wildland instead of residential or industrial land, as was the plan, thereby wasting farmland which is naturally limited in Vietnam. However, one of the important achievements of urbanization and industrialization is an increase in incomes in rural households from the non-agriculture sector which has contributed to rural poverty reduction [47]. Urbanization will continue to be an important feature of Vietnam's development [47]. This means farmland conversion will continue and both challenges and opportunities from urbanization will continue to lead to the transformation of agriculture in the future.

\subsection{The Nexus between ALAFU and Agriculture at Affected Communes}

Based on the nature of ALAFU, we formed the nexus between ALAFU and agriculture, as shown in Figure 1 below. In our research, ALAFU includes three elements, which are agriculture land acquisition (ALA), a compensation and support program for losers of farmland, and urbanization activities on acquired land areas such as construction of roads, buildings, and infrastructure. Firstly, ALA is the process by which the state withdraws the land use rights of agricultural land users. As a result, access to agricultural land for households has been reduced. Secondly, compensation and support programs occur after ALA. Almost all ALAFU projects in Vietnam could not compensate land losers with a new land area, instead of with cash. Along with compensation, there is a support program to recover livelihoods after ALA, which provides food for all people in affected households for 12 months and vocational training courses. If affected workers do not want to take these courses, ALA projects can provide them with cash to help them find new jobs. As a result, the compensation and support program has the potential to change the affected people's household capacities, financial assets, and facilities. This monetary compensation can assist affected households in improving their financial capacity and access to utilities. Finally, urbanization occurring on acquired land areas could include the construction of residences, office buildings, roads, power systems, and other facilities that support urban living. These activities then upgrade infrastructure in and out of affected communities that could support agricultural activities and attract a number of people to move there to live or to work, resulting in increasing agricultural product consumption. These activities also create many opportunities for non-farming jobs, causing labor in affected households to leave agricultural fields. All of these above changes from three elements of ALAFU together can contribute to the transformation of agricultural activities, including crop cultivation and animal breeding in the affected households. The transformation could be seen in the changes in cost and benefits, labor division, the form of agricultural activities, and challenges and opportunities for agriculture as well. 


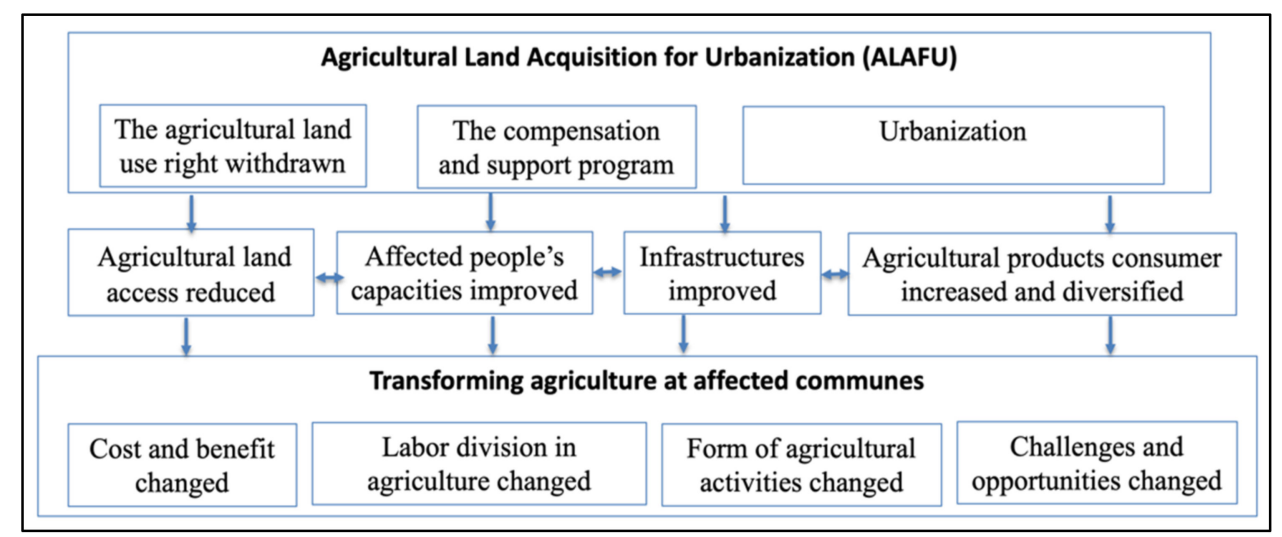

Figure 1. The nexus between ALAFU and agriculture in affected communities.

\section{Research Method}

\subsection{Study Site}

Being a central province of Vietnam with a severe climate and poor soil resources, agriculture here does not have many advantages compared with other provinces in the North, South and highlands of Vietnam [52]. Rice is a staple crop that is important in Thua Thien Hue province's agriculture. However, it faces challenges because the soil quality of agricultural land areas is poor, and flooding and drought are becoming increasingly severe [52]. Since the 2000s, however, under the pressure of economic development, the provincial authority has promoted urbanization and industrialization by expanding Hue city to the south of province. As a result, between 2010 and 2015, 7083 ha of agricultural land has been acquired to convert to non-agricultural land. In 2014 the government planned to extend Hue city to be five times larger, so 19,000 ha of agricultural land will be converted in the period 2016-2020 [52,53]. The share of income from agriculture in the province was reduced from $21 \%$ in 2005 to $11.62 \%$ in 2017 [54,55]. the urbanization rate reached $52.7 \%$ and the average income per person was 41 million Vnd/year (around 1700\$) and for rural areas only was 35 million Vnd/year (around 1500\$) in 2019 [56].

Huong Thuy Town has a total of 45,466 ha of land area, located in the south of Thua Thien Hue province and bordering Hue City. Since 2010, it has been planned to develop industry and tourism, so agricultural land has been reduced by $6.3 \%$ (around $3527.8 \mathrm{ha}$ ) in the period 2005-2018 due to conversion to non-agricultural land. Given the land use plan of the province, 2000 ha of agricultural land has been converted to support urbanization in the period 2019-2020. The share of agricultural land area has been reduced to $69.56 \%$ in 2020 , instead of $80.9 \%$ in 2010 [57]. Most of the converted agricultural land area is rice land and forest land. The main agricultural activities here include crop cultivation, animal breeding, and forestry. Rice has been the main crop, occupying $90 \%$ of total agricultural land. Besides this, perennial crops such as pepper and Thanh Tra (a special crop in Thua Thien Hue Province that belongs to the grapefruit family) have been developed in recent years. Other crops such as vegetables and grains have only been cultivated in a limited area due to the severe climate and poor soil quality. Regarding livestock, cattle (cow and buffalo), pigs, and poultry (chicken and duck) are the main domestic animals. Of these, the breeding scale of cattle has been reduced gradually because of diminishing grassland, whereas the breeding scale of pigs and poultry has increased due to industrial breeding methods. However, contribution of agriculture to the income structure of the town decreased from $6.62 \%$ in 2010 to $3.4 \%$ in 2017. The average amount of income per person of the town was 51.6 million Vnd/year in 2018 (around 2250\$) [57]. In 2019, the rate of urbanization here reached nearly $70 \%$ [56].

Thuy Van and Thuy Thanh communes, two of eleven communes of Huong Thuy Town, were selected to be the study sites because more than 200 ha of former agricultural land there has been acquired to construct industrial parks, roads, and buildings. These communities have been planned to be a part of Hue city in the near future. Most households 
here had a diverse income source from both agriculture and non-agriculture before ALA. In 2020, the average income per person in these communities reached around 45 million Vnd per year, which is higher than that of the whole province. Agriculture contributes around $38 \%$ of the income structure, and rice production is one of the main agricultural activities. The map of study sites is shown in Figure 2.

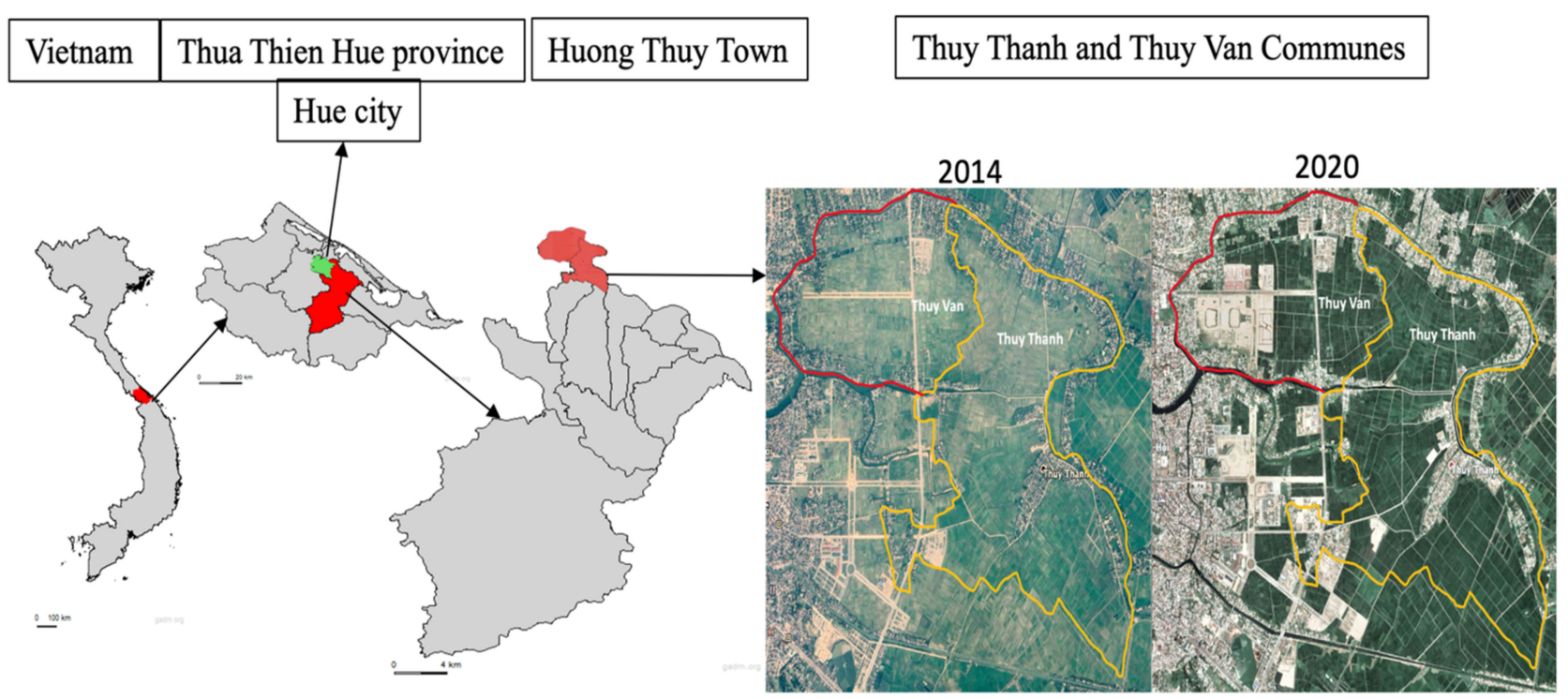

Figure 2. Study sites. (Source: Global Administrative Areas (GADM) 2018 and google earth 2021).

\subsection{Research Method}

The mixed method, which originated in the social sciences, promotes the systematic integration or mixing of quantitative and qualitative data within a single investigation or long-term program of inquiry. This method works well for intervention research [58,59]. Using this method, the researcher can prioritize both qualitative and quantitative methods, or emphasize one of the two [60]. This study aims to understand the impacts of ALAFU on the livelihoods of local people, namely on agricultural activities, to suggest policy intervention. Therefore, we applied the mixed-method and prioritized the qualitative method. The quantitative data is collected and analyzed to show the basic dimensions of each agricultural activity between before and after, such as farmland scale, cost, and income. While qualitative data explains the impacts of ALAFU through listing, categorizing, and ranking all the reasons for the change in each agricultural activity by local people, who deeply understand the changing progress in agricultural activities. The challenges and opportunities of agricultural activities are also discovered by using qualitative data collected from the SWOT analysis. We attached much importance to these data because they are the voices of local people that are very significant in suggesting the interventions or solutions for community development.

Because qualitative data collection takes a long time, while the time and financial issues for the study are limited, we could not conduct a household survey with a huge number of households. This could have led to the statistical data system in this study not being strong enough to run a regression model, which is often used to show the impacts of the independent variables on dependent variables. To compensate for this limitation, we have tried to collect as much qualitative data as possible during field trips.

\subsection{Data Collection}

To collect the valuable qualitative and quantitative data, the rural rapid appraisal method was used because it supports researchers having good communication and interaction with all stakeholders, especially local people, while collecting data [61]. The tools from 
this method for data collection were applied in this study including household surveys, group discussions, in-depth interviews, village walking and observation study sites.

To conduct the household surveys, 50 of over 200 affected households whose land was reduced by more than $50 \%$ of total former agricultural land area due to ALA were randomly selected from a list of affected households provided by the Commune People Committee. We have designed a questionnaire for the survey to collect quantitative data regarding the income of households, farmland area, and costs and income generated from each agricultural activity of the affected household after ALAFU (2017) and before (2012). This questionnaire also considered the causes of the change of each activity.

Parallel with the survey, we held group discussions that included 10 representatives of affected households to identify and classify the causes of the changes, challenges, and opportunities for each agricultural activity. We requested that participants list all the reasons, and use a couple of comparisons, to rank the importance of each reason. Based on this, we identified the causes, challenges, and opportunities associated with ALAFU. In addition, the in-depth interviews with six key informants (the head of a farmer's union, the head of the people's committee, and local people) at study sites were also conducted by using the checklist. We asked open questions that focused on their opinions about general information regarding agriculture, its transformation, and the contribution of ALAFU to the transformation. Last, but not least, we visited and walked around the villages multiple times to observe and take pictures of the agricultural activities in different seasons. During these walks, we talked randomly with any farmers or local people who were willing to share their stories and views about agriculture and ALAFU to obtain more information. This information was mostly used to supplement or cross-check the data from the affected households, group discussions, and in-depth interviews with key informants.

All these primary data were coded and entered into excel software to analyze statistical data such as percentages and average values of indexes relating to each agricultural activity. The qualitative data was filtered and documented as stories, quotes, and pictures which support from the quantitative data to give comprehensive arguments for each research problem.

The secondary data relating to agricultural development and ALAFU were collected from documents, ALAFU project proposals, annual reports at levels, and statistical books. Other data sources such as scientific papers and daily magazines relating to research topics were referred to as well.

\section{Finding}

\subsection{Characteristics of Survey Households}

The basic information of 50 surveyed households at times before and after ALAFU is listed in Table 1. The average income per person has increased from 19.7 in 2012 to 31.5 million in 2017, and it is a little higher compared with the average income of the whole study site at present. The share from agricultural activities to household income structure dropped from $45.6 \%$ to $34 \%$, lower than that of the whole study site. This means the surveyed households' livelihood still depend rather much on agriculture. On average, each household is compensated 138 million Vnd for losing agricultural land of 0.225 ha. This amount is very significant to develop or rehabilitate the livelihoods of affected households after ALAFU, and especially to invest in non-farming jobs and small business. 
Table 1. Characteristics of survey households.

\begin{tabular}{|c|c|c|c|}
\hline & Unit & Before (2012) & After (2017) \\
\hline Average age of household leader before ALAFU (2012) & Year old & 48.8 & 53.8 \\
\hline Average income/person/year & Million Vnd & 19.7 & 31.5 \\
\hline $\begin{array}{l}\text { Contribution of agriculture to total income household } \\
\text { structure }\end{array}$ & $\%$ & 45.6 & 34 \\
\hline Average agricultural land area of household & $\mathrm{Ha}$ & 0.305 & 0.08 \\
\hline Average agricultural acquired land area & $\mathrm{Ha}$ & & 0.225 \\
\hline Average amount of compensated cash & Million Vnd/HH & & 138 \\
\hline Average number of persons in household & Person & & 4.1 \\
\hline Average number of laborers in household & Labor & & 2.4 \\
\hline
\end{tabular}

Note: 1 USD $\approx 20,000$ Vnd in 2012; $\approx 22,000$ Vnd in 2018 (Source: Household survey, 2018-2019).

\subsection{Changing of Crops Cultivation}

Regardless of the scarcity of agricultural land resources, crop cultivation is a longstanding agricultural activity that plays an important role in contributing to rural livelihoods in Viet Nam and in our study sites as well. The staple crops are rice, maize, sweet potato, cassava, cafe, and pepper, of which the rice is the most important and popular crop because it is the main food in all Vietnamese families. Unfortunately, most of the agricultural land area that has been converted to urban land during the urbanization process consisted of rice paddies in the lowland areas. Therefore, the impacts of ALAFU on cultivation activity is very clear. In our study site, the impacts are investigated and shown in Table 2.

Table 2. Changing of crop cultivation activities of affected households before and after ALAFU. (N = 50) (Source: Data from household survey 2018-2019).

\begin{tabular}{|c|c|c|c|c|c|c|c|}
\hline \multirow[b]{2}{*}{ Indicators } & \multirow[b]{2}{*}{ Unit } & \multicolumn{2}{|c|}{ Rice } & \multicolumn{2}{|c|}{ Potted flower } & \multicolumn{2}{|c|}{ Vegetable } \\
\hline & & $\begin{array}{l}\text { Before } \\
(2012)\end{array}$ & $\begin{array}{l}\text { After } \\
(2017)\end{array}$ & $\begin{array}{l}\text { Before } \\
(2012)\end{array}$ & $\begin{array}{l}\text { After } \\
(2017)\end{array}$ & $\begin{array}{l}\text { Before } \\
(2012)\end{array}$ & $\begin{array}{l}\text { After } \\
(2017)\end{array}$ \\
\hline $\begin{array}{l}\text { Percentage of surveyed } \\
\text { household participated in }\end{array}$ & $\%$ & 100 & 22 & 10 & 34 & 40 & 22 \\
\hline Average scale & Ha/household & 0.305 & 0.08 & $500 *$ & $890 *$ & 0.01 & 0.015 \\
\hline Number of harvests per year & Harvest & 2 & 2 & 1 & 1 & 3 & 4 \\
\hline Total cost & Million vnd/year & 11.6 & 3.8 & 25 & 100 & 1.2 & 4.8 \\
\hline $\begin{array}{l}\text { Average income of active } \\
\text { household }\end{array}$ & Million vnd/year & 13.5 & 3.5 & 50 & 100 & 6.3 & 16.8 \\
\hline $\begin{array}{l}\text { Its share of income in surveyed } \\
\text { households }\end{array}$ & $\%$ & 16.7 & 0.6 & 6.1 & 26.1 & 3.1 & 2.8 \\
\hline
\end{tabular}

* Note: Flowers are planted immediately into a pot from the beginning stage, so the production scale of this crop is measured by the number of flowerpots.

Because rice is a main and important food crop for Vietnamese families, we counted all surveyed households participating in rice cultivating activity, no matter whether their activity was for family food only or for income generating purposes. However, with flowers and vegetables, just households that planted for an income-generating purpose were counted because the planting scale of these crops for family food is too small to investigate the costs and income. The data in Table 2, compiled from the household surveys, shows the clear change of each crop in the affected households. The indicators of rice cultivation consisting of percentage of households, scale, income, and the average contribution to household income was reduced greatly from $88 \%$ to $22 \%$, from 0.305 ha/household to 
$0.08 \mathrm{ha} /$ household, from 13.5 million Vnd to 3.5 million Vnd, and from $16.7 \%$ to $0.6 \%$, respectively. In contrast, these indicators of Potted Flower Plantation (PFP) increased sharply from $10 \%$ to $34 \%$, from 500 flowerpots / household to 1000 flowerpots / household (around two pots per m2), from 50 million Vnd to 100 million Vnd, and from $6.1 \%$ to $25.1 \%$, respectively, howerver. Vegetable cultivation also increased slightly above the average scale and income, but the number of households dropped sharply so its share of household income was reduced slightly. However, the percentage of surveyed households planting vegetables for family food purposes only is not much different before and after ALAFU. At present, PFP has been developing and, being the highest income crop, its share of income of surveyed households has increased up to $26.1 \%$, however, it occurs mainly on temporory land area or space around residential land area (Figure 3). In contrast, rice has been a marginal crop associated with lower income, and its share of income of surveyed households is almost zero.

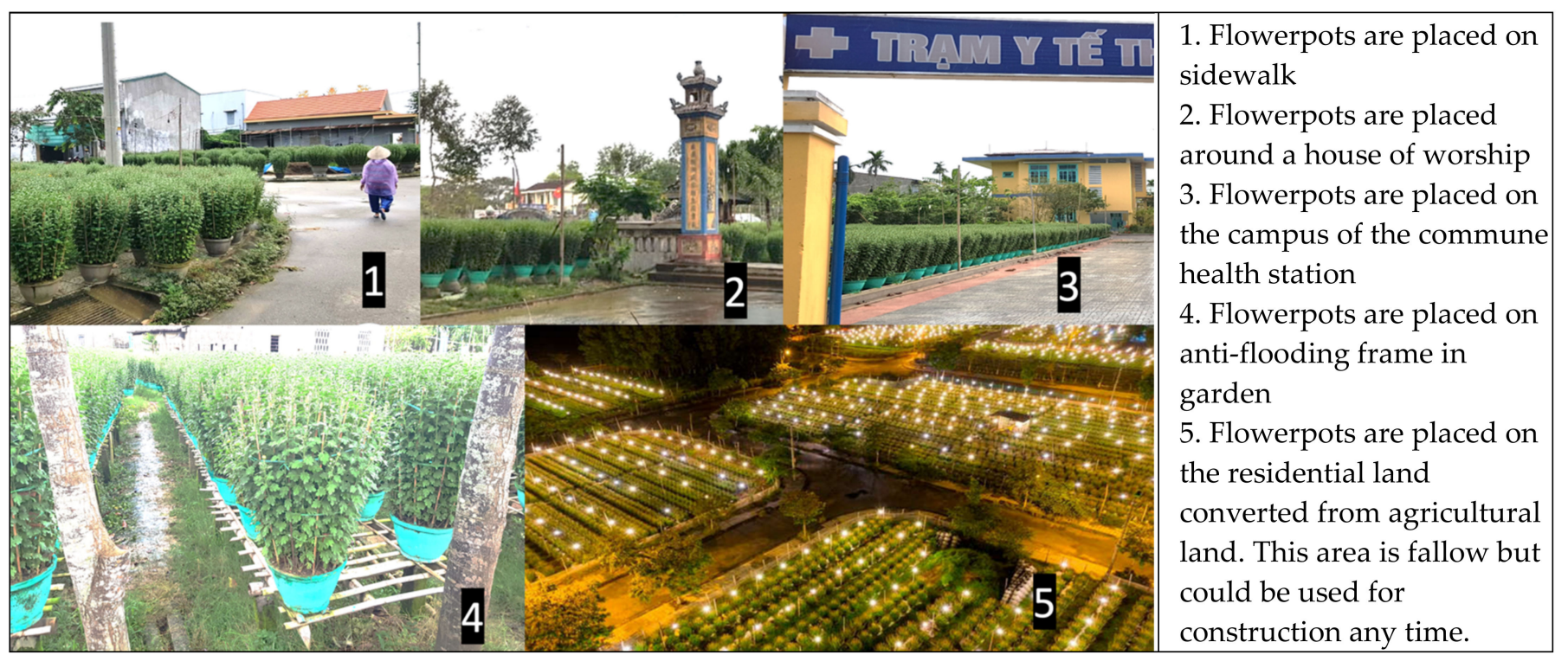

Figure 3. PFP occurs mainly on the temporary land areas or spaces in the study site (Source: Picture number 1, 2, 3, 4 taken by main author 2019, picture number 5 taken by photographer Nguyen Phong, 2019).

"The PFP had been developed by few households before ALAFU, however after ALAFU, it has quickly been the main income of more than 300 households in our commune including non-affected and affected households. Most of these households undertake by themselves all steps of the PFP by consisting of making cement flowerpots in March -April, germinating saplings and preparing land from May-Jun, planting saplings into the cement pots, caring from July to December, and sale at the Tet festival (Lunar new year). Therefore, the labors participating in this activity are busy all year, they don't have to take the second job but their income is still good. In general, a main female labor of the family works on this activity as a full-time job. Compared with other crops, PFP requests highly about technique, financial capital and number of working day, in return, the income from this activity is higher".. (Source from a depth interview an officer of famer union)

To discover how these changes relate to ALAFU, we investigated the causes obtained by the household surveys, group discussions, and in-depth interviews, and then analyzed the data. The results are listed in Table 3. The causes were listed and categorized into four groups including ALA, compensation, urbanization, and other. We mixed statistics data from household surveys and rankings from group discussions. The reasons for the change of each crop are rather different. 
Table 3. Reasons for the change of crop cultivation activities of affected households (Source: data from household survey and group discussion 2018-2019).

\begin{tabular}{|c|c|c|c|c|c|c|c|}
\hline \multirow{2}{*}{\multicolumn{2}{|c|}{ Reasons of the Change of Crop Cultivation }} & \multicolumn{2}{|c|}{ Rice $(n=50)$} & \multicolumn{2}{|c|}{ Flower $(n=17)$} & \multicolumn{2}{|c|}{ Vegetable $(n=20)$} \\
\hline & & \multirow{2}{*}{$\begin{array}{c}\text { Percentage } \\
78\end{array}$} & \multirow{2}{*}{$\begin{array}{c}\text { Rank } \\
2\end{array}$} & \multirow[t]{2}{*}{ Percentage } & \multirow[t]{2}{*}{ Rank } & \multirow[t]{2}{*}{ Percentage } & \multirow[t]{2}{*}{ Rank } \\
\hline ALA & $\begin{array}{l}\text { Farmland fragmentation is } \\
\text { exacerbated }\end{array}$ & & & & & & \\
\hline Compensation & $\begin{array}{l}\text { Compensated cash is used } \\
\text { to develop other jobs }\end{array}$ & 30 & 3 & & & & \\
\hline \multirow{4}{*}{ Urbanization } & Increasing non-farm jobs & 60 & 1 & & & 80 & 2 \\
\hline & Value of crop is increased & & & 100 & 2 & 100 & 3 \\
\hline & Consumer market increased & & & 100 & 1 & 100 & 1 \\
\hline & Infrastructure is upgraded & & & 52.9 & 4 & & \\
\hline \multirow{3}{*}{ Other } & Field-rat damage & 30 & 4 & & & & \\
\hline & Severe climate & 20 & 5 & & & & \\
\hline & Need less farmland & & & 47 & 3 & & \\
\hline
\end{tabular}

Note: interviewee can select more than one reason of the change, ranking done by group discussion.

Only the surveyed households participating in each crop cultivation were asked the reasons for the changes, so there are 50,17, and 22 surveyed households participating in rice cultivation, PFP, and vegetable plantation, respectively. With rice cultivation, there are many reasons for the changes. However, almost all surveyed households $(78 \%$ and $60 \%$ ) selected "farmland fragmentation is exacerbated" and "increasing non-farm jobs" as the main reasons for reducing rice cultivation, of which the second one is ranked the most important reason by group discussion. It was explained that

"Rice is a low-value crop and rice land fragmentation is more exacerbated by ALA; meanwhile non-farm jobs are more and more available due to the rapid urbanization. As a result, farmers are attracted to these non-farm jobs instead of keeping rice cultivation. Moreover, drought, flood, and field-rat damage are more and more severe, leading to more difficulties for rice cultivation. Rice land abandonment has been occurring". (Source: in-depth interview with a farmer)

The survey data shows that $78 \%$ of surveyed households have left this activity after ALAFU, although they still access a small area of rice land. Of this small area that remains, $58 \%$ of households either sublet or give their rice land free to others, and $20 \%$ completely abandoned their rice land.

While walking around the study sites, we collected a story from a farmer who supplies the service of land preparation and rice harvesting by machines:

"We worked directly with rice planters inside and outside commune since 2010 and can deeply understand about rice cultivation. Under the impacts of urbanization, not only in our commune but also in many other communes around, farmers have increasingly left rice cultivation. This leads to two different trends, one is rice land abandonment, the other is rice land concentration in a few households up to 1ha per household by renting or receiving rice land from others. While the rice land abandonment caused increasing rat damage, the land concentration caused increasing benefit of rice cultivation. Rice planters are often elders and mid-age women who have fewer opportunities to take non-farm jobs or have to stay for housework. They also spend a short time for rice cultivation (around 20 days per season)". (Source: a story of Nguyen Van A, Thuy Van commune) 
However, during the in-depth interview with the local authority, they revealed that: "We knew but still could not control about the rice land concentration because the households themselves negotiated each other to sublet or give free the rice land. However, we also recognized rice land concentration does not only maintain rice cultivation but also creates high benefit for rice planter" (Source: in-depth interview of an officer of the Commune's People Committee).

While many affected households have left rice cultivation to focus totally on nonfarming jobs, some others have switched to the PFP. All potted flower planters selected "value of crop is increased", "infrastructure is upgraded" and "consumer market extended" as reasons for developing PFP, of which the last one is ranked as the most important reason.

"Increasing urban population due to urbanization created a high consumer market of the potted flower on the Tet festival. In addition, after ALAFU, the upgraded infrastructure including electricity system, water, and road has also supported much for PFP such as watering, setting up temporary lighting system and transportation". (source: a statement in group discussion)

\subsection{Changing of Animal Breeding}

Before the 1990s, the livestock at the rural household level related closely with crop cultivation that supported food sources for it. In return, it supported the pulling capacity and organic fertilizer to facilitate crop cultivation. Out of that, the function of this activity mainly supplemented meat for family on important events (deaths, anniversaries, new year's party, etc.). The popular animals were poultry (chickens and ducks), pigs, and cattle (cows and buffalo). The animals were freely bred on natural spaces such as rice paddies, grasslands, gardens, backyards, and rivers. Since the 2000s, however, this activity has been developed by applying the industrial breeding model. It has since been one of the main income sources of households. The food sources for animals also no longer totally depend on crop cultivation and natural sources. Instead, industrial food sources have commonly been used. So, how has ALAFU impacted the animal breeding of affected households? The surveyed data are shown in Table 4.

Table 4. Changing of animal breeding activity of affected households before and after ALAFU. $n=50$ (Source: data from household survey, 2018-2019).

\begin{tabular}{|c|c|c|c|c|c|c|c|}
\hline & \multirow[b]{2}{*}{ Unit } & \multicolumn{2}{|c|}{ Cattle } & \multicolumn{2}{|c|}{ Pig } & \multicolumn{2}{|c|}{ Poultry } \\
\hline & & $\begin{array}{l}\text { Before } \\
\text { (2012) }\end{array}$ & $\begin{array}{l}\text { After } \\
(2017)\end{array}$ & $\begin{array}{l}\text { Before } \\
\text { (2012) }\end{array}$ & $\begin{array}{l}\text { After } \\
(2017)\end{array}$ & $\begin{array}{l}\text { Before } \\
(2012)\end{array}$ & $\begin{array}{l}\text { After } \\
\text { (2017) }\end{array}$ \\
\hline Percentage of household & Percentage & 20 & 4 & 52 & 10 & 44 & 10 \\
\hline Scale & Unit/cycle & 2.6 & 3 & 10 & 20 & 50 & 100 \\
\hline Number of breeding cycle & Cycle/year & 1 & 1 & 2.5 & 2.5 & 2.5 & 3.2 \\
\hline $\begin{array}{c}\text { Average cost of active } \\
\text { household }\end{array}$ & Million vnd/year & 12 & 15 & 70 & 166.7 & 6.25 & 25.6 \\
\hline $\begin{array}{l}\text { Average income of active } \\
\text { household }\end{array}$ & Million vnd/year & 13 & 18 & 20.5 & 45 & 6.1 & 8 \\
\hline $\begin{array}{l}\text { Its share of surveyed } \\
\text { household's income }\end{array}$ & $\%$ & 3.2 & 0.5 & 13.2 & 3.4 & 3.3 & 0.6 \\
\hline
\end{tabular}

The same as with crop cultivation, we only count surveyed households whose animal breeding is oriented as an income-generating activity in Table 4 . First, we can see the number of bred animals in study sites is monotonous and the breeding scale is small, both before and after ALAFU. The percentage of the surveyed households participating in breeding fell dramatically to under $10 \%$ of all animals. However, the average breeding scale increased. For example, the scale of pig livestock increased from 10 unit/cycle to $20 \mathrm{unit} /$ cycle and that of poultry increased from 50 unit to $200 \mathrm{unit} / \mathrm{cycle}$. The average 
scale has increased not because these breeding households increased the scale of their operations, but because only breeding households operating at the larger scale before ALAFU continued breeding after ALAFU. Despite this, the contribution of each breeding activity to the surveyed household's income structure has been reduced. However, similar to the vegetable plantations, the number of households breeding chickens as a food source for family use (meat and eggs) is still rather high ( $50 \%$ of surveyed households).

In Table 5, there are 10, 26, and 22 surveyed households who participate in cattle, pig, and poultry breeding, respectively. With cattle breeding, the main reasons for households stopping after ALAFU are "grassland is reduced" and "non-farm jobs are available", of which the last one is ranked as the most important reason. Meanwhile, with pig and poultry breeding, "The commune is merged with the city" and "Disease breakout" are the main reasons, of which the first one is ranked as the most important cause.

"As the agricultural development plan of the province, we have focused to develop breeding oriented industrial mode with big scale in rural communes that are far away from Hue city to avoid environmental pollution and disease as well, so reducing breeding at affected communes is reasonable and the breeding households understood this situation too." (Source: in-depth interview of an agricultural officer). However, a few households still continue their breeding because "they have tried to take advantage of the firm facility that has been built before ALAFU. However, they have also had the plan to leave this activity when the commune is merged into the city next year.". (Source: in-depth interview of a breeding household)

Table 5. Reasons for the change of livestock activity of affected households (Source: data from household survey and group discussion 2018-2019).

\begin{tabular}{|c|c|c|c|c|c|c|c|}
\hline \multirow{2}{*}{\multicolumn{2}{|c|}{ Reasons for the Change }} & \multicolumn{2}{|c|}{ Cattle $(n=10)$} & \multicolumn{2}{|c|}{ Pig $(n=26)$} & \multicolumn{2}{|c|}{ Poultry $(n=22)$} \\
\hline & & \multirow{2}{*}{$\begin{array}{c}\text { Percentage } \\
50\end{array}$} & \multirow{2}{*}{$\begin{array}{c}\text { Rank } \\
2\end{array}$} & \multirow[t]{2}{*}{ Percentage } & \multirow[t]{2}{*}{ Rank } & \multirow[t]{2}{*}{ Percentage } & \multirow[t]{2}{*}{ Rank } \\
\hline ALA & Grassland is reduced & & & & & & \\
\hline \multirow{3}{*}{ Urbanization } & Increasing non-farm jobs & 80 & 1 & & & & \\
\hline & Free space is reduced & & & 50 & 2 & & \\
\hline & $\begin{array}{l}\text { The commune is merged } \\
\text { with the city }\end{array}$ & & & 50 & 1 & 100 & 1 \\
\hline \multirow{2}{*}{ Disease breakout } & Africa Swine Flue & & & 76.9 & 3 & & \\
\hline & H5N1 & & & & & 100 & 2 \\
\hline
\end{tabular}

Note: interviewee can select more than one reason for the change, ranking conducted by group discussion.

\subsection{Challenges and Opportunities}

Animal breeding does not have much opportunity to develop as an income generating activity of these communities in the future, because of merging with the city. As a result, we only analyzed strengths, weaknesses, opportunities, and threats (SWOT) related to crop cultivation through group discussion. The results are shown in Table 6. 
Table 6. Results of SWOT analysis of crop cultivation in the affected community (Source: Information from group discussion, 2018).

\begin{tabular}{|c|c|c|c|c|}
\hline Activity & Strengths & Weaknesses & Opportunities & Threats \\
\hline PFP & $\begin{array}{l}\text { + A high value crop } \\
+ \text { A high adaptative capacity } \\
\text { with flooding and loss of } \\
\text { farmland } \\
+ \text { A landscape value crop } \\
\text { + Experienced laborers } \\
\text { + Good income }\end{array}$ & $\begin{array}{l}+ \text { High investment } \\
+ \text { High technique } \\
\text { requirement } \\
+ \text { Aged laborers }\end{array}$ & $\begin{array}{l}+ \text { A good consumer market } \\
+ \text { An opportunity to be one } \\
\text { of the destinations in the } \\
\text { trade villages in the } \\
\text { tourism network of Huong } \\
\text { Thuy Town }\end{array}$ & $\begin{array}{l}\text { + Spaces to put } \\
\text { flowerpots will be } \\
\text { narrowed due to } \\
\text { urbanization }\end{array}$ \\
\hline $\begin{array}{c}\text { Rice } \\
\text { cultivation }\end{array}$ & $\begin{array}{l}\text { + Experienced laborers } \\
+ \text { A main food crop }\end{array}$ & $\begin{array}{l}+ \text { A low value crop } \\
+ \text { Aged and feminized } \\
\text { laborers }\end{array}$ & $\begin{array}{l}\text { + Rice land is concentrated } \\
+ \text { Application of } \\
\text { agricultural machines }\end{array}$ & $\begin{array}{l}\text { + Severe climate } \\
+ \text { Rat damage }\end{array}$ \\
\hline $\begin{array}{l}\text { Vegetable } \\
\text { Plantation }\end{array}$ & + Experienced laborers & $\begin{array}{l}\text { + Unsuitable soil quality } \\
+ \text { Aged and feminized } \\
\text { laborers }\end{array}$ & + A good consumer market & $\begin{array}{l}\text { + Severe climate } \\
\text { + Garden land will be } \\
\text { narrowed due to } \\
\text { urbanization }\end{array}$ \\
\hline
\end{tabular}

\section{Discussion}

Farmland is the most important requirement for agriculture production [62], so reducing access to farmland due to ALAFU could decrease agricultural production. This is especially true with crop cultivation activity that depends the most on farmland [63-65]. Therefore, many studies recommend that ALAFU should be carefully considered under the high pressure of urbanization [66]. In our study, each agricultural activity of the affected households has changed in different ways. The previous studies have generally concluded that ALAFU leads to a reduction in agricultural production. However, our research findings show that ALAFU caused different trends in changes in each agricultural activity.

\subsection{Rice Land Fragmentation and Abandonment}

However, PFP as a horticultural activity has been increasing and is becoming the main income-generating activity. This trend has not popularly appeared in affected communes by ALAFU around the country, but has been mentioned in some recent studies about urban agricultural development $[23,67]$. The previous studies have generally concluded that ALAFU leads to a reduction in agricultural production.

Rice cultivation, which heavily depends on agricultural land, has sharply decreased. After ALAFU, besides decreasing the scale of rice cultivation as an inevitable consequence of ALA, the number of households participating in this activity has also decreased sharply. Twenty percent of households abandoned the remaining rice land and $58 \%$ sublet or gave the remaining land area to others. As a result, the share of rice cultivation of household's income is reduced. This situation coincides with many previous studies in Vietnam and developing countries $[2,64,65,68,69]$. Increasing non-farming jobs due to urbanization was ranked as the most important reason for leaving rice cultivation for households. This means that in the context of ALAFU, rice cultivation and rice land access have not been significant to livelihoods of the households surveyed. In reality, stopping rice cultivation (giving rice land away or abandoning rice land) has recently occurred not only in affected rural communities due to ALA, but also in non-affected rural communities. This is especially true in rural communities in the north and central parts of Vietnam, where farmland fragmentation is higher than other places [7,70-73]. This situation has also been warned against in many previous studies in Vietnam, China, Thailand, Indonesia about agricultural land fragmentation and the impacts of urbanization on rice production $[11,34,74,75]$. A review of global farmland abandonment shows that farmland abandonment has occurred primarily in developed countries in Europe and North America through changing socioeconomic factors such as urbanization and migration [76-79]. 
Although this finding has been mentioned in many countries, increasing farmland abandonment in Vietnam, a developing country with a scarcity of farmland resources, is very serious. Furthermore, the abandoned land in developed countries is mainly located in mountainous and hilly areas due to their unfavorable farming conditions [76-79], but that in Vietnam this is located in peri-urban or lowland areas, where both soil quality and infrastructure are the most suitable for rice cultivation. Some studies in China and Thailand have also shown this problem [73]. The finding also indicated that ALAFU projects do not only directly occupy the rice land area through ALA but also indirectly accelerate rice land abandonment. Losing an agricultural land area for ALAFU projects has been accepted as a trade-off for the urbanization process that Vietnam and other developing countries have recognized, but rice land abandonment as the unexpected impact of ALAFU has been not carefully considered and controlled yet. It reflects the unreasonable planning of urbanization strategy that could lead to unsustainable development and threaten food security.

\subsection{ALAFU Versus Animal Breeding at Household Level}

Just as with rice cultivation, animal breeding at the household level has been at a small scale and has mainly played the role of food provision for families before ALA. This situation is very common in rural areas of Vietnam [5]. Although it does not depend much on agricultural land, it also has been shown to decline after ALAFU. This change, however, relates to urbanization and disease more than ALA. The breeding process has no opportunity to maintain itself or develop in the affected communities because the urbanization process has gradually merged these communities into the city. This means that breeding at any level is either limited or requested to move on to other places that are far away from urban residential areas. Moreover, the Africa Swine Flu (ASF) and H5N1 epidemics broke in the period 2016-2018 around the country and caused almost all breeding households to lose all of their business [80]. Our study sites are not an exception and, as a result, the number of surveyed households participating in breeding was sharply reduced at the survey time. This change, however, coincides with the breeding development plan of the country, and the government has also oriented towards increasing breeding operations at larger scales and reducing breeding at the household level. The number of big breeding farms increased 3,38 times between 2011 and 2017 [81]. As part of the plan in 2017, 70\% of the output of pig production was to be from big farms. During the period 2012-2017, the number of pig breeding households was reduced by five percent per year [82]. Therefore, the ALAFU, especially urbanization, by creating more non-farm jobs for local people, has supported the livestock development plan of the country. In another word, the ALAFU is the main factor that has broken up traditional animal breeding at the household level.

\subsection{Development Peri-Urban Agriculture after ALAFU}

Opposite the reduction in rice cultivation and animal breeding is the development of PFP, a horticultural activity. PFP has been notably increasing after ALAFU. It has been the main income source of $34 \%$ of surveyed households and its share of the average income of surveyed households increased by up to $26.1 \%$. Not only affected households but also non-affected households participated in this activity. In our case study, PFP has been developed due to advantages associated with urbanization, not by ALA. The potted flower consumer market is higher and higher every year due to the increase of urban dwellers, and PFP is more convenient due to the upgraded infrastructure system such as water, electricity and roads. Potted flowers are a non-food crop but have a high value. Although the cost of PFP is high and the planting technique is rather complicated, its income is also higher than other crops or some non-farming jobs. Therefore, the potted flower planters have tried to learn the techniques well and have taken advantage of all free spaces alternating between the residential land areas and temporary fallow land areas (due to the delayed ALAFU) to develop their business. 
PFP is an agricultural activity which has a high value, a good consumer market, a good adaptive capacity to the severe climate (flooding), and a low dependence on farmland. In the context of Vietnamese agriculture, where the value of agricultural production is low, climate change is more serious and farmland resources are poor and constrained by urbanization, developing agricultural activities such as the PFP is interesting and therefore promoted [5,15,83-85]. Furthermore, PFP could contribute to urban landscape value and support the trade village tourism mode around Hue City, which is rather significant for sustainable urban development. Unfortunately, while urban agriculture has been mentioned as a necessary solution for sustainable urban development in previous studies $[19,20,86]$, it has received little attention in the plan of social economic development of study sites after ALAFU (peri urban areas). The evidence is that the local authorities have recognized the PFP as a good livelihood activity, but they still have not allocated any permanent land areas for this activity nor made any plans to retain or develop it. This will lead to challenges to PFP in the future.

In general, disregarding horticultural development has popularly been seen in affected communes in Vietnam because both affected people and local authorities believe that moving to non-farming jobs is the best option for the livelihoods of households $[2,65]$. Furthermore, after being a peri-urban area, the price of residential land has been rocketing, so people have tried to convert garden land (normally it is around the house) to resident land in order to obtain benefits [87]. In some cases, horticulture has been a long-lasting traditional livelihood activity and the main income of households since before ALAFU. People have tried to maintain it but have changed from vegetables to flowers and ornamental plants to obtain a higher income $[23,67,88]$. Some studies in China and India have also revealed that horticulture in the peri-urban areas has to face challenges associated with scarcity of land, water, and labor, and opportunities such as good markets and high demand for horticultural production $[89,90]$ To avoid these challenges, urban agriculture in Japan, which has long been the primary source of food for city dwellers, has been given much attention. Japan has released a new conceptual approach called "Satoyama", which states that the surrounding areas of small cities must be planned for agriculture and play important roles in agro-ecological production, food, and other services. Furthermore, payment for urban ecosystem services, the establishment of a consumption-production network, and the integration of urban agriculture development into the national environmental strategy are applied to the development of sustainable urban agriculture [91].

\section{Conclusions and Recommendation}

\subsection{Conclusions}

ALAFU has caused a reduction in rice cultivation in both the number of households and rice land size, not only by losing rice land through ALA, but also by abandoning the rice land of farmers due to urbanization. The decreasing rice cultivation in our study also coincides with many previous studies in Vietnam and other countries about rice production and rice land abandonment. However, ALAFU projects have not considered this phenomenon yet in estimating and assessing the damage to rice cultivation in particular, and to agriculture in general. ALAFU, on the other hand, has provided an opportunity for the development of PFP, a horticultural activity, through urbanization benefits. PFP has increased and is the main income of $34 \%$ of surveyed households. Developing a new form of cultivation is not popular in the communities affected by ALAFU, but in this study, PFP is called a kind of peri-urban agriculture which has also been considered in many previous studies in peri-urban or urban areas. Unfortunately, the development of PFP has not been predicted yet. This has resulted in challenges such as a lack of space or land area for PFP, but also a waste paddy land. Besides this, many surveyed households have still maintained vegetable plantations and chicken breeding as family food-supplying activities. As a result, agriculture still remains after ALAFU, but the total contribution of agriculture to the income structures of households has been reduced from $45.6 \%$ to $34 \%$. 
These research findings also contribute to more evidence that agricultural land, although it is a crucial material for agricultural development, does not totally decide the existence or development of agricultural activities, but other factors, including the consumer market, infrastructure and income. Moreover, besides ensuring agricultural land use rights, the increasing value and income of agricultural activities is an important force for farmers to improve their capabilities themselves and achieve success in agriculture. This could be important evidence for land use planners, agricultural developers, and agricultural development programs.

\subsection{Recommendation}

Agriculture can still develop as a form of PUA in affected communities after ALAFU. However, to achieve sustainable agricultural development, firstly we recommend that there be more studies about the impacts of ALAFU on agriculture to create a comprehensive database to warn about food insecurity associated with ALAFU. Secondly, we recommend that, besides looking for solutions to minimize the area of agricultural land acquisition that was mentioned in many previous studies, the ALAFU projects should predict the situation of abandoned farmland after ALAFU. This effort could calculate the total amount of the real farmland damage caused by ALAFU projects, thereby supporting better decision-making, and forecasting better agricultural transformation after ALAFU. In addition, to minimize paddy land abandonment, the paddy land remaining in affected communities should be concentrated at the same time with ALA. The government should design and pilot an agricultural land concentration policy by revising the current policy of ALA, such as acquiring the remaining land area after ALLFU and then delivering it to farmers who demonstrate a long-term commitment to crop cultivation. In non-effected communities, the farmland consolidation policy should continue to be efficiently implemented to reduce farmland fragmentation. Finally, instead of allowing agriculture to develop freely as a marginal activity as it is now, local authorities should create a master plan for agricultural development in affected communes, such as allocating a given land for PFP. At the national level, urban agriculture development should be seriously considered and the solutions to urban agriculture from Japan should be referred to while making plans for land-use, urban expansion, and agricultural development that are moving toward peri-urban and urban agriculture.

Author Contributions: Conceptualization, N.P.T., M.K. and H.F.; methodology, N.P.T.; software, N.P.T.; validation, N.P.T.; formal analysis, N.P.T.; investigation, N.P.T.; resources, M.K. and H.F.; data curation, N.P.T.; writing—original draft preparation, N.P.T.; writing—review and editing, N.P.T., M.K. and H.F.; visualization, M.K. and H.F.; supervision, M.K. and H.F.; project administration, M.K. and H.F.; funding acquisition, M.K. and H.F. All authors have read and agreed to the published version of the manuscript.

Funding: This research was funded by Ministry of education and Training of Vietnam and DAAD scholarship via providing the PhD scholarship for the first author from 2017-2020 at the Institute of Geography, Cartography, GIS and Remote Sensing Department, University of Goettingen, Germany.

Institutional Review Board Statement: Not applicable.

Informed Consent Statement: Not applicable.

Data Availability Statement: Not applicable.

Conflicts of Interest: The authors declare no conflict of interest.

\section{References}

1. Rigg, J. Poverty and Livelihoods after Full-Time Farming: A South-East Asian View. Asia Pac. Viewp. 2005, 46, 173-184. [CrossRef]

2. Thai, P.H.; Tuan, B.A.; Le Thanh, D. Is Nonfarm Diversification a Way Out of Poverty for Rural Households? Evidence from Vietnam in 1993-2006. SSRN Electron. J. 2010, 17. [CrossRef]

3. Tuyen, T.Q. A Review on the Link between Nonfarm Activities, Land and Rural Livelihoods in Vietnam and Developing Countries. MPRA 2012, 2012, 55850. 
4. Fan, P.; Ouyang, Z.; Nguyen, D.D.; Nguyen, T.T.H.; Park, H.; Chen, J. Urbanization, Economic Development, Environmental and Social Changes in Transitional Economies: Vietnam after Doimoi. Landsc. Urban Plan. 2019, 187, 145-155. [CrossRef]

5. World Bank. Transforming Vietnamese Agriculture: Gaining More from Less; Vietnam Development Report; World Bank: Washington, DC, USA, 2016.

6. Vietnam Government. Báo Cáo Quốc Gia Về Kế Hoạch Sủ Dụng Đất Đai Đến Năm 2020 Và Kế Hoạch Sủ Dụng Đất Giai Đoạn 2016-2020 (National Report Land Use Planning up to 2020 and Planing Land Use for Peroid 2016-2020); Vietnam Government: Ha Noi, Vietnam, 2016.

7. Liem, P.S. Nông dân bỏ ruộng: Thách thức lớn đối với người làm chính sách (Famer leaving agricultural land: Big challenge for policy maker); Nhà xuất bản nông nghiệp: Hanoi, Vietnam, 2015; pp. 254-259.

8. UKEssays. The Importance of Agriculture in Developing Countries Economics Essay. 2018. Available online: https:// www.ukessays.com/essays / economics / the-importance-of-agriculture-in-developing-countries-economics-essay.php?vref=1 (accessed on 8 May 2021).

9. Phuong, M.L.; Le, N.P.; Lebailly, P. Contribution of Urban Agriculture at Household Level in Northern Vietnam: Case Study in Trau Quy Town, Gia Lam District, Hanoi City. Asian J. Agric. Rural. Dev. 2016, 6, 229-239. [CrossRef]

10. Yu, J.; Wu, J. The Sustainability of Agricultural Development in China: The Agriculture-Environment Nexus. Sustainability 2018, 10, 1776. [CrossRef]

11. Vien, T.D. Nông Nghiệp Việt Nam: Những Vấn Đề Tồn Tại (The Gaps in Vietnamese Agriculture). 2020. Available online: https: / / tiasang.com.vn/-quan-ly-khoa-hoc/Nong-nghiep-Viet-Nam-Nhung-van-de-ton-tai-26635 (accessed on 9 April 2021).

12. Tung Xuan, D. Tổng Quan về Ô Nhiếm Nông Nghiệp ở Việt Nam: Ngành Chăn Nuôi; World Bank: Washington, DC, USA, 2017.

13. Nguyen, T.H. Tổng Quan về Ô Nhiếm Nông Nghiệp ở Viẹt Nam: Ngành Trồng Trọt; World Bank: Washington, DC, USA, 2017.

14. Nguyen, H.Q.; Warr, P. Land Consolidation as Technical Change: Economic Impacts in Rural Vietnam. World Dev. 2020, 127, 104750. [CrossRef]

15. Borton, J. Backgrounder: Agriculture 4.0 in Vietnam. 2020. Available online: https://www.geopoliticalmonitor.com/ backgrounder-agriculture-4-0-in-vietnam/ (accessed on 2 March 2021).

16. Wu, Y.; Xi, X.; Tang, X.; Luo, D.; Gu, B.; Lam, S.K.; Vitousek, P.M.; Chen, D. Policy Distortions, Farm Size, and the Overuse of Agricultural Chemicals in China. Proc. Natl. Acad. Sci. USA 2018, 115, 7010-7015. [CrossRef]

17. OECD; FAO. Special Focus: Southeast Asia: OECD-FAO Agricultural Outlook 2017-2026; OECD Publishing: Paris, France, 2017; ISBN 978-92-64-27547-8.

18. Lynch, K.; Binns, T.; Olofin, E. Urban Agriculture under Threat. Cities 2001, 18, 159-171. [CrossRef]

19. Kulak, M.; Graves, A.; Chatterton, J. Reducing Greenhouse Gas Emissions with Urban Agriculture: A Life Cycle Assessment Perspective. Landsc. Urban Plan. 2013, 111, 68-78. [CrossRef]

20. Pribadi, D.O.; Pauleit, S. The Dynamics of Peri-Urban Agriculture during Rapid Urbanization of Jabodetabek Metropolitan Area. Land Use Policy 2015, 48, 13-24. [CrossRef]

21. Nugent, R.; Bakker, N.; Dubbeling, M.; Gündel, S.; Sabel-Koschella, U.; Zeeuw, H.D. The Impact of Urban Agriculture on the Household and Local Economies; Deutsche Stiftung fur Internationale Entwicklung (DSE), Zentralstelle fur Ernahrung und Landwirtschaft: Feldafing, Germany, 2000.

22. Kiminami, L.; Furuzawa, S.; Kiminami, A. Impacts of Multi-Functionality of Urban Agriculture on the Creative Classes in Global Mega City: Focusing on Shanghai in China. Asia Pac. J. Reg. Sci. 2019, 3, 487-515. [CrossRef]

23. Le, N.P.; Dung, N.M. Multifunctionality of Peri-Urban Agriculture: A Case Study in Trau Quy Commune, Hanoi City. Int. J. Rural Dev. Environ. Health Res. 2018, 2, 8-19. [CrossRef]

24. GSO. Thông Cáo Báo Chí về Kết Quả Sơ Bộ Tổng Điều Tra Nông Thôn, Nông Nghiệp và Thủy Sản Năm 2016 (Press Release on Initial Results of the Rural, Agriculture and Fisheries Census 2016); GSO: Ha Noi, Vietnam, 2017. Available online: https://www.gso.gov.vn/sukien/2019/04/thong-cao-bao-chi-ve-ket-qua-so-bo-tong-dieu-tra-nong-thon-nong-nghiep-va-thuy-san-nam-2016/ (accessed on 2 January 2020).

25. Bingxin, Y.; Tingju, Z.; Breisinger, C.; Nguyen, N.M. Examine the Agriculture, Poverty, and Climate Change Nexus in Vietnam. In Proceedings of the 2012 International Association of Agricultural Economists Conference, Foz do Iguacu, Brazil, 18-24 August 2012.

26. OECD. Agricultural Policies in Viet Nam 2015; OECD Food and Agricultural Reviews; OECD: Paris, France, 2015; ISBN 978-92-6423514-4.

27. Lowder, S.K.L.; Skoet, J.; Singh, S. What Do We Really Know about the Number and Distribution of Farms and Family Farms Worldwide? Background Paper for The State of Food and Agriculture 2014, ESA Working Paper No. 14-02.; Food and Agriculture Organization of the United Nations: Rome, Italy, 2014.

28. Tan, S. Land Fragmentation and Rice Production: A Case Study of Small Farms in Jiangxi Province. Ph.D. Thesis, Wageningen University, Wageningen, The Netherlands, 2005.

29. GSO. Niên Giám Thông Kê 2012 (Statistical Yearbook of Vietnam); Nhà xuât bản thống kê: Ha Noi, Vietnam, 2012.

30. Ha Ngan. 2020: Năm "Bản Lề" Cho Ngành Chăn Nuôi Phát Triển. Available online: https://antvietnam.com/2020-nam-ban-lecho-nganh-chan-nuoi-phat-trien/ (accessed on 20 February 2021).

31. Vietnamese Government. Luật Đất Đai 2013 (The Land Law 2013); Vietnamese Government: Hanoi, Vietnam, 2014. 
32. World Bank. Sứa Đổi Luật Đất Đai Để Thúc Đẩy Phát Triển Bền Vũng ở Việt Nam (Revising the land law to promote sustainable development in Vietnam); World Bank: Ha Noi, Vietnam, 2012.

33. Huong, N.L. Rijksuniversiteit Groningen Farmers' Land Tenure Security in Vietnam and China: Legislative Changes and Challenges. Ph.D. Thesis, The University of Groningen, Groningen, The Netherlands, 2014.

34. Hung, P.V.; MacAulay, T.G.; Marsh, S.P. The Economics of Land Fragmentation in the North of Vietnam. Aust. J. Agric. Resour. Econ. 2007, 51, 195-211. [CrossRef]

35. Markussen, T. Land Issues in Vietnam 2006-2014 Markets, Property Rights, and Investment; WIDER: Helsinki, Finland, 2015.

36. York, A.M.; Shrestha, M.; Boone, C.G.; Zhang, S.; Harrington, J.A.; Prebyl, T.J.; Swann, A.; Agar, M.; Antolin, M.F.; Nolen, B.; et al. Land Fragmentation under Rapid Urbanization: A Cross-Site Analysis of Southwestern Cities. Urban Ecosyst. 2011, 14, 429-455. [CrossRef]

37. Ty, P.H.; Phuc, N.Q.; van Guus, W. Vietnam in the Debate on Land Grabbing: Conversion of Agricultural Land for Urban Expansion and Hydropower Development. In In the Global Land Grab: Beyond the Hype; Zed Books: London, UK, 2014.

38. Dang Hung, V. Improving Land Acquisition and Voluntary Land Conversion in Vietnam; World Bank: Hanoi, Vietnam, 2009.

39. Campbell, K.; Chan, L.; Custot, J.; Elmqvist, T.; Galt, R.; Katti, M.; Mader, A.; Persic, A.; Oliveira, J.P.D.; Rudd, A. Cities and Biodiversity Outlook: Action and Policy. Bytes 2012, 1, 5203881. [CrossRef]

40. Seto, K.C.; Guneralp, B.; Hutyra, L.R. Global Forecasts of Urban Expansion to 2030 and Direct Impacts on Biodiversity and Carbon Pools. Proc. Natl. Acad. Sci. USA 2012, 109, 16083-16088. [CrossRef]

41. Surjan, A.; Parvin, G.A.; Shaw, R. Impact of Urban Expansion on Farmlands. In Urban Disasters and Resilience in Asia; Elsevier: Amsterdam, The Netherlands, 2016; pp. 91-112. ISBN 978-0-12-802169-9.

42. Factsandetails Problems Faced by Farmmers in China and Threats to Agriculture. Available online: http://factsanddetails.com/ china/cat9/sub63/item346.html\#chapter-13 (accessed on 20 April 2019).

43. Ministry of Natural Resources of the People's Republic of China. China Land and Resources Statistical Yearbook; Geological Press: Beijing, China, 2018.

44. Shrestha, R.P. Monitoring Farmland Loss and Projecting the Future Land Use of an Urbanized Watershed in Yogyakarta, Indonesia. J. Land Use Sci. 2013, 8, 59-84. [CrossRef]

45. VOV5. Vietnam Seeks Solutions for Problems Caused by Rapid Urbanization. Available online: https://english.vietnamnet.vn/ $\mathrm{fms}$ / society/192232/vietnam-seeks-solutions-for-problems-caused-by-rapid-urbanization.html (accessed on 1 March 2020).

46. MOC. Báo Cáo Đánh Giá Quá Trình Đô Thị Hoá ở Việt Nam Gian Đoạn 2011-2020 và Mục Tiêu và Nhiệm vụ Giai Đoạn 2021-2030 và Kế Hoach Giai Đoan 2021-2025 (Assessment of Urbanization Process in Vietnam Peroid 2011-2020, Target and Mission of Peroid 2021-2030 and Plan for Period 2021-2025); MOC: Ha Noi, Vietnam, 2019.

47. World Bank. Vietnam's Urbanization at a Crossroads: Embarking on an Efficient, Inclusive, and Resilient Pathway; The World Bank: Washington, DC, USA, 2020.

48. GSO. Niên Giám Thông Kê 2017 (Statistical Yearbook of Vietnam); Nhà xuất bản thống kê: Ha Noi, Vietnam, 2017.

49. World Bank. Vietnam 2035: Towards Prosperity, Creativity, Equity and Democracy; World Bank: Washington, DC, 2016.

50. Thanh, M. Về Chuyển Dịch Cơ Cấu Lao Động Nông Thôn Sau Thu Hồi Đất" (Regarding Restructuring of Rural Labor after Land Acquisition). Tạp Chí Cộng Sản 2009, 15, 183.

51. Setsuko, S. Urbanization, Jobs, and the Family in the Mekong Delta, Vietnam. J. Comp. Fam. Stud. 2018, 49, 93-108.

52. Dinh Van Huế Mở Rộng Thành Phố Gấp 5 Lần, Người Dân Đồng Thuận. Available online: https:/ / baotainguyenmoitruong.vn/ hue-mo-rong-thanh-pho-gap-5-lan-nguoi-dan-dong-thuan-298006.html (accessed on 20 May 2020).

53. Son, Q. Thừa Thiên Huế Vững Bước Lên Độ Thị Loại 1. 2014. Available online: https:/ / baodautu.vn/thua-thien-hue-vung-buoclen-do-thi-loai-1-d15086.html (accessed on 20 May 2018).

54. UBND. Báo Cáo Kinh Tế Xã Hội Tỉnh Thưà Thiên Huế 2001-2005 (the annual report of social economic development, Thua Thien Hue province 2001-2005); UBND: Thua Thien Hue, Vietnam, 2005.

55. UBND. Báo Cáo Kinh Tế Xã Hỏi Tỉnh Thừa Thiên Huế 2017 (The anual report of social economic development, Thua Thien Hue province 2017); UBND: Thua Thien Hue, Vietnam, 2017.

56. GSO. Báo Cáo Kinh Tế Xã Hội Tỉnh Thừa Thiên Huế 2019 (The annual report of the Social-Economic development of Thua Thien Hue Province 2019). Available online: https://thuathienhue.gov.vn/vi-vn/Thong-tin-kinh-te-xa-hoi/tid/Tinh-hinh-kinh-te-xahoi-thang-12-va-ca-nam-2019/newsid/2D0A031B-D412-47B3-9FAD-AB3400FC1C54/cid/B7F8F059-11A6-44B1-B4A3-AA150 OE63BA2 (accessed on 20 January 2020).

57. UBND. Báo Cáo Quy Hoach và Sủ Dụng Đất Đai 2010-2020 thị xã Hương Thuy (Report of land use planning in Huong Thuy Tow 2010-2020); UBND: Thua Thien Hue, Vietnam, 2020.

58. Designing and Conducting Mixed Methods Research. Aust. N. Z. J. Public Health 2007, 31, 388. [CrossRef]

59. Hitchcock, J.H. An Introduction to Mixed Methods Research.; SAGE Thousand: Oaks, CA, USA, 2017; ISBN 978-1-4739-9171-2.

60. Burns, A. Mixed Methods. In Qualitative Research in Applied Linguistics; Heigham, J., Croker, R.A., Eds.; Palgrave Macmillan: London, UK, 2009; pp. 135-161. ISBN 978-0-230-21953-3.

61. Crawford, I.M. Marketing Research and Information Systems; Marketing and Agribusiness Texts; Food and Agriculture Organization of the United Nations: Rome, Italy, 1997; ISBN 978-92-5-103905-2.

62. Mundlak, Y. Agriculture and Economic Growth: Theory and Measurement; Harvard University Press: Cambridge, MA, USA, 2000; ISBN 978-0-674-00228-9. 
63. Phuc, N.Q.; van Westen, A.; Zoomers, A. Compulsory Land Acquisition for Urban Expansion: Livelihood Reconstruction after Land Loss in Hue's Peri-Urban Areas, Central Vietnam. Int. Dev. Plan. Rev. 2017, 39, 99-121. [CrossRef]

64. Chung, D.K. Tích Tụ và Tập Trung Đất Đai: Cơ Sở Lý Luận và Thực Tiễn Cho Phát Triển Nông Nghiệp Hàng Hóa ở Việt Nam. Tạp Chí Khoa Học Nông Nghiệp Việt Nam 2018, 16, 412-424.

65. Hai, N.T. Tác Giá Tác Động Của Chuyển Đổi Đất Nông Nghiệp Sang Đất Phi Nông Nghiệp Trong Quá Trình Đô Thị Hoá Tại Các Đô Thị Vệ Tinh Của Thành Phố Huế, Thù̃a Thiên Huế; Đại học Nông Lâm Huế: Hue, Vietnam, 2017.

66. Nguyen, T.H.T.; Tran, V.T.; Bui, Q.T.; Man, Q.H.; de Vries Walter, T. Socio-Economic Effects of Agricultural Land Conversion for Urban Development: Case Study of Hanoi, Vietnam. Land Use Policy 2016, 54, 583-592. [CrossRef]

67. Bakker, N. Growing Cities, Growing Food: Urban Agriculture on the Policy Agenda; A Reader on Urban Agriculture; ZEL: Feldafing, Germany, 2000; ISBN 978-3-934068-25-4.

68. Thao, N.T.B. Acquisition of Agricultural Land for Urban Development in Peri-Urban Areas of Vietnam: Perspectives of Institutional Ambiguity, Livelihood Unsustainability and Local Land Grabbing; Okayama University: Okayama, Japan, 2015.

69. Furuseth, O.J. Agricultural Land Conversion: Background and Issues. J. Geogr. 1982, 81, 84-93. [CrossRef]

70. Ngoc, P. Bờ Xôi Ruộng Mật Cũng Bỏ Hoang. Available online: https:/ / www.phunuonline.com.vn/dat-bo-xoi-ruong-mat-cungbo-hoang-a1415484.html (accessed on 9 March 2021).

71. Viet, H. Nghệ An: Nông Dân Bỏ Ruộng Tràn Lan. Available online: https://www.tienphong.vn/kinh-te/nghe-an-nong-dan-boruong-tran-lan-979871.tpo (accessed on 9 March 2021).

72. Hung, N. Tình Trạng Nông Dân Bỏ Ruộng Ngày Càng Tăng. Available online: http:/ / tnnn.hoinongdan.org.vn/sitepages/news/ 1093/45366/tinh-trang-nong-dan-bo-ruong-ngay-cang-tang (accessed on 15 March 2017).

73. Seto, K.C.-Y.; Solecki, W.; Griffith, C. (Eds.) The Routledge Handbook of Urbanization and Global Environmental Change, 1st ed.; Routledge, Taylor \& Francis Group: London, UK, 2016; ISBN 978-0-415-73226-0.

74. Tuyen, T.Q.; Huong, V.V. The Impact of Land Loss on Household Income: The Case of Hanoi's Sub-Urban Areas, Vietnam. Int. J. Bus. Soc. 2014, 15, 339-358.

75. Tan, S.; Heerink, N.; Qu, F. Land Fragmentation and Its Driving Forces in China. Land Use Policy 2006, 23, 272-285. [CrossRef]

76. Li, S.; Li, X. Global Understanding of Farmland Abandonment: A Review and Prospects. J. Geogr. Sci. 2017, 27, 1123-1150. [CrossRef]

77. Ustaoglu, E.; Collier, M.J. Farmland Abandonment in Europe: An Overview of Drivers, Consequences, and Assessment of the Sustainability Implications. Environ. Rev. 2018, 26, 396-416. [CrossRef]

78. Zhang, Y.; Li, X.; Song, W.; Zhai, L. Land Abandonment under Rural Restructuring in China Explained from a Cost-Benefit Perspective. J. Rural Stud. 2016, 47, 524-532. [CrossRef]

79. Zhou, T.; Koomen, E.; Ke, X. Determinants of Farmland Abandonment on the Urban-Rural Fringe. Environ. Manag. 2020, 65, 369-384. [CrossRef] [PubMed]

80. Que, N.N.; Linh, P.T.N.; Thang, T.C.; Thuy, N.T.; Thinh, N.T.; Karl, M.R.; Hung, N.V. Economic Impacts of African Swine Fever in Vietnam; CGIAR: Montpellier, France, 2020.

81. Giao, H.K. Số Lượng Trang Trại Chăn Nuôi ở Việt Nam (2011-2017) Tăng Nhanh (Number of livestock farm in Vietnam 2011-2017 increased quickly). Available online: http:/ / nhachannuoi.vn/so-luong-trang-trai-chan-nuoi-o-viet-nam-2011-2017-tang-nhanh/ (accessed on 20 March 2020).

82. Ha Ngan Ngành Chăn Nuôi Lợn: Bức Tranh 10 Năm Tới? Available online: http:/ /www.minhhieu.com.vn/chi-tiet-tin-tuc/55 /Nganh-chan-nuoi-lon--Buc-tranh-10-nam-toi-.html (accessed on 1 March 2020).

83. Bich Hong Kinh Tế 2020: Nông Nghiệp Chuyển Dịch Mạnh Mẽ Từ Sản Xuất Tới Thị Trường. Available online: https://bnews. vn/kinh-te-2020-nong-nghiep-chuyen-dich-manh-me-tu-san-xuat-toi-thi-truong/181827.html (accessed on 1 January 2021).

84. Thuy, B. Tập Trung Xây Dựng Nền Nông Nghiệp Việt Nam Theo Hướng Hiện Đại. Available online: https:/ / www.tin247.com/ tap-trung-xay-dung-nen-nong-nghiep-viet-nam-theo-huong-hien-dai-3-28316766.html (accessed on 10 March 2021).

85. Thanh, H.X.; Anh, T.T.; Quang, L.T.; Giang, D.T.; Phuong, D.T.T. Food Security in the Context of Vietnam's Rural-Urban. Linkages and Climate Change; International Institute for Environment and Development: London, UK, 2013; ISBN 978-1-84369-988-0.

86. Food and Agriculture Organization (FAO). Urban and Peri-Urban Agriculture; Food and Agriculture Organization: Rome, Italy, 2001.

87. Linh, D. Land Prices around Hanoi Jump. Ha Noi Time. 2020. Available online: http://hanoitimes.vn/increasing-prices-ofhanois-suburban-land-reasons-and-advice-315107.html (accessed on 10 March 2021).

88. Brody, L.; Binns, T.; Dixon, A.B. The Dynamics of Urban Agriculture in Hanoi, Vietnam. Field Actions Sci. Rep. 2010, 1, 1-8.

89. Leo, V.D.B.; Van, D.T.H.; Shi, X.; Ben, K. Towards Integrated Urban and Horticultural Planning in Hanoi and Nanjing; Alterra: Wageningen, The Netherlands, 2006.

90. Surakshitha, N.C.; Vasanth, K.; SharathKumar, M. Urban and Peri-Urban Horticulture Issues in Horticultural Science; Agrotechnology: Barcelona, Spain, 2012.

91. Moreno-Peñaranda, R. Japan's Urban Agriculture: Cultivating Sustainability and Well-Being; Development \& Society: Food Security, Agriculture, Asia, Urban Development. 2011. Available online: https:/ / ourworld.unu.edu/en/japans-urban-agriculturecultivating-sustainability-and-wellbeing (accessed on 8 March 2021). 